\title{
Character Association and Path Analysis Studies for Yield and its Component Characters in Rice (Oryza sativa L.)
}

\author{
K. Sudeepthi", D.P.B. Jyothula, Y. Suneetha and V. Srinivasa Rao \\ Department of Genetics and Plant Breeding, ANGRAU, Bapatla- 522101, Andhra Pradesh, India \\ *Corresponding author
}

\begin{tabular}{|l|}
\hline Ke y w o r d s \\
Character association, \\
Path analysis, Rice.
\end{tabular}

A B S T R A C T
The present investigation was carried out in rice to measure the character association and direct and indirect effects of component characters on yield using 33 genotypes. The experiment was laid out in a randomized complete block design with two replications at the Agricultural College Farm Bapatla during kharif 2015. The association studies revealed that the genotypic correlations were, in general higher than the phenotypic correlations and thus suggested that the observed relationships among the characters were due to genetic factors. Grain yield per plant exhibited significant positive association with days to $50 \%$ flowering, days to maturity, plant height, number of productive tillers per plant and number of filled grains per panicle and non-significant positive association with panicle length and test weight. Path analysis studies revealed that improvement of grain yield per plant is possible through manifestation of plant height, number of productive tillers per plant and number of filled grains per panicle. Therefore, direct selection for any of the character would be effective for yield improvement in rice with simultaneous improvement of rest of the character.

\section{Introduction}

Rice is an important staple food of almost half of the world population and referred to as "Global Grain". According to the FAO (FAO 2004), the director general has stated "Rice is a symbol of both cultural identity and global unity". Rice is grown worldwide over an area of 161 million hectares with total production of 494.2 million tonnes. Among rice growing countries, India has largest area under rice in the world i.e. 43.86 million hectares and ranks second in production with 105.48 million tonnes. (Ministry of Agriculture, 2014-2015). Rice is the staple food for more than 65 per cent of the people of India. Rice grain yield is a quantitative character governed by many genes (polygenes) and is highly influenced by environment too. Yield represents the ultimate product from the interaction of all the plant characters. However, certain plant characters could prove useful as selection criteria in breeding for high yield. The selection of parents based on yield alone is often misleading Selvaraj et al., (2011), Rangare et al., (2012). Information on association of yield attributes and their direct and indirect effects on grain yield are of paramount significance. Knowledge regarding the relative contribution of individual traits to yield may be accomplished by correlation studies, however simple correlation does not provide adequate information about the contribution of each factor towards yield. 
Hence path analysis is of much importance in any plant breeding programme. Correlation in combination with path analysis would give a better insight into cause and effect relationship between different pairs of characters. Keeping this in view, the present investigation was undertaken to gather some useful information on character association and path analysis in a set of 33 rice genotypes.

\section{Materials and Methods}

The present investigation was carried out to measure the character association and path coefficients using 33 genotypes of rice comprising 10 parents, 21 hybrids and 2 checks (Table 1). The experiment was laid out in a Randomized Complete Block Design with two replications at Agricultural College Farm, Bapatla during kharif 2015, which is located at $15^{\circ} 54^{\prime} \mathrm{N}$ Latitude, $80^{\circ} 25^{\prime} \mathrm{E}$ longitude, $5.49 \mathrm{~m}$ above the mean sea level.

Thirty days old seedlings of each genotype were transplanted in three rows of 3.0 metre length by adopting a spacing of $20 \times 15 \mathrm{~cm}$ between row to row and plant to plant. Standard agronomic practices were followed throughout the crop growth period to raise a good crop. Observations were recorded on 10 randomly selected plants for eight metric traits viz., plant height $(\mathrm{cm})$, number of productive tillers per plant, panicle length $(\mathrm{cm})$, number of filled grains per panicle, test weight $(\mathrm{g})$, grain yield per plant $(\mathrm{g})$ in each replication. Days to $50 \%$ flowering and days to maturity were recorded on plot basis.

Phenotypic and genotypic correlations were worked out by using the formulae suggested by Falconer (1964). The partitioning of genotypic and phenotypic correlation coefficient in to direct and in direct effects was carried out using the procedure suggested by Dewey and Lu, (1959). The estimated values were compared with table values of the correlation coefficient to test the significance of the correlation coefficient prescribed by Fisher and Yates (1963).

\section{Results and Discussion}

The analysis of variance for each character revealed that the rice genotypes in the present study differed amongst themselves at $\mathrm{p}=$ 0.01 . This indicated the presence of ample genetic variation among the genotypes for each quantitative character.

The relationship among yield contributing characters as well as their influence on yield provides information for exercising selection pressure for genetic improvement in seed yield. The estimates of genotypic and phenotypic correlation among eight characters are presented in Table 2. The genotypic and phenotypic path coefficients are represented by path diagram (Fig. 1 and 2).

Character association revealed that genotypic correlations were in general higher than the phenotypic correlations and thus suggested that the observed relationship among the characters was due to genetic factors or it might be due to modified effect of environment on character association at the genetic level. This is in agreement with the findings reported by Kole et al., (2008). Grain yield per plant was found to be positively and significantly correlated with the traits days to $50 \%$ flowering, days to maturity, plant height, number of productive tillers per plant and number of filled grains per panicle at both genotypic and phenotypic levels indicating the relative utility of these traits for selection with respect to grain yield. The positive correlation of grain yield with various traits was supported by Swain and Reddy (2006) for days to $50 \%$ flowering, Bornare et al., (2014) for days to maturity, Saikumar et al., (2014) for plant height, Basavaraja et al., 
(2013) for number of productive tillers per plant and Ratna et al., (2015) for number of filled grains per panicle. The characters panicle length and test weight showed non- significant positive correlation with grain yield at both genotypic and phenotypic levels. Similar results reported by Borbora et al., (2005) for both panicle length and test weight.

Fig.1 Phenotypic path diagram showing direct and indirect effects of yield components on grain yield plant ${ }^{-1}$ in rice (Oryza sativa L.)

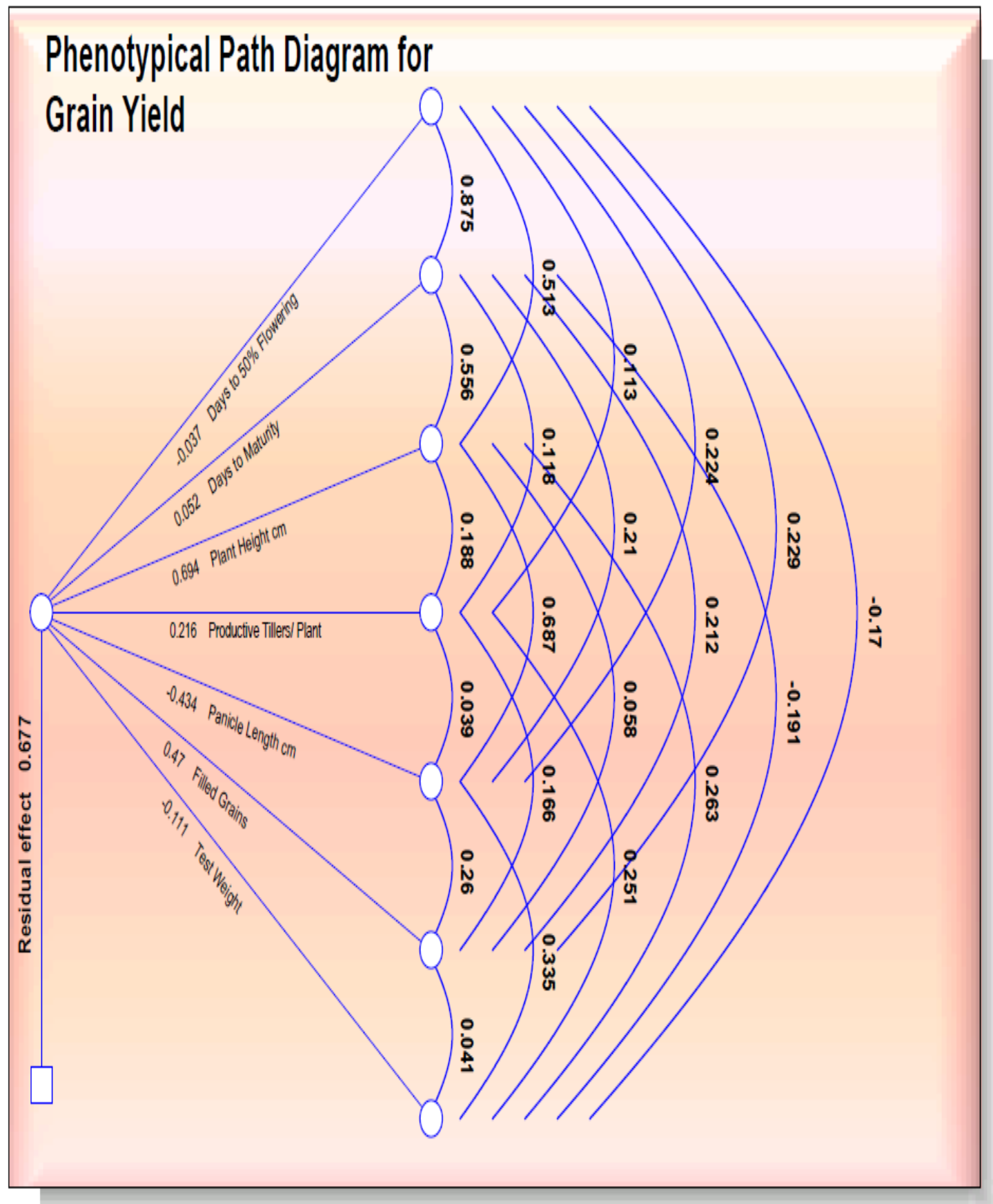


Fig.2 Genotypic path diagram showing direct and indirect effects of yield components on grain yield per plant in rice (Oryza sativa L.)

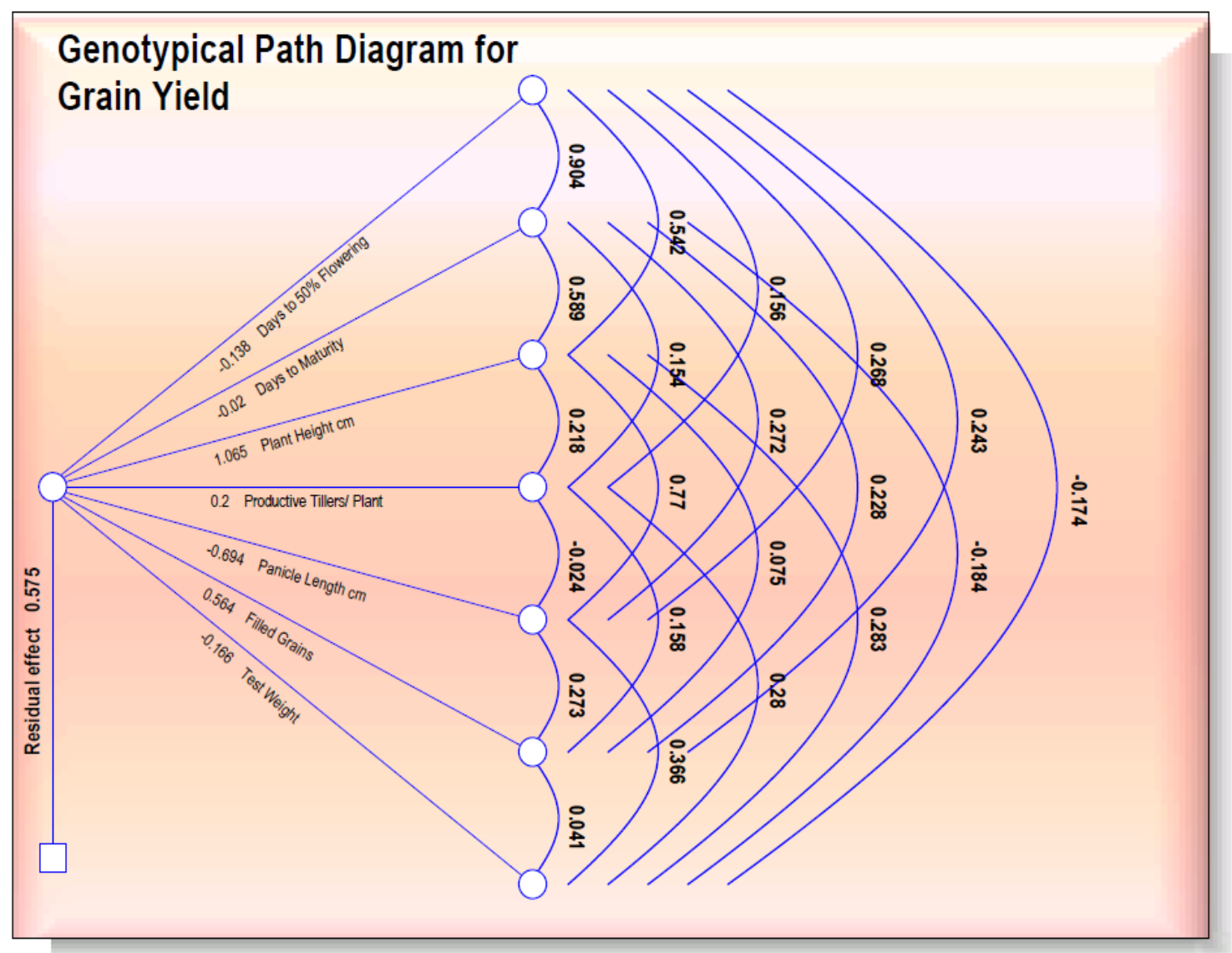

Table.1 Experimental material used in the study

\begin{tabular}{|l|l|l|}
\hline S. No. & Genotype & \multicolumn{1}{|c|}{ Source } \\
\hline & CMS Lines & \\
\hline 1 & IR 58025A & IRRI, Philippines \\
\hline 2 & IR 68888A & IRRI, Philippines \\
\hline 3 & IR 68897A & IRRI, Philippines \\
\hline & TESTERS & \\
\hline 1 & NLR 40065 & ARS, Nellore, India \\
\hline 2 & NLR 33654 & ARS, Nellore, India \\
\hline 3 & NLR 33057 & ARS, Nellore, India \\
\hline 4 & NLR 3083 & ARS, Nellore, India \\
\hline 5 & NLR 3449 & ARS, Nellore, India \\
\hline 6 & NLR 3042 & ARS, Nellore, India \\
\hline 7 & WGL 44 & \\
\hline & CHECKS & \\
\hline 1 & MTU 1010 (Varietal check) & ARS, Maruteru, India \\
\hline 2 & DRRH 2 (Hybrid check) & IIRR, Hyderabad, India \\
\hline
\end{tabular}


Table. 2 Correlation matrix for yield and yield component traits in rice (Oryza sativa L.)

\begin{tabular}{|c|c|c|c|c|c|c|c|c|c|}
\hline S.No. & Character & $\mathbf{P} / \mathbf{G}$ & $\begin{array}{c}\text { Days to } \\
50 \% \\
\text { Flowering }\end{array}$ & $\begin{array}{l}\text { Days to } \\
\text { Maturity }\end{array}$ & Plant Height & $\begin{array}{c}\text { Number of } \\
\text { Productive } \\
\text { Tillers plant }^{-1}\end{array}$ & Panicle Length & $\begin{array}{c}\text { Number of } \\
\text { Filled } \\
\text { Grains } \\
\text { panicle }^{-1}\end{array}$ & Test Weight \\
\hline \multirow[t]{2}{*}{1.} & \multirow{2}{*}{$\begin{array}{l}\text { Days to } 50 \% \\
\text { Flowering }\end{array}$} & $\mathrm{P}$ & 1.0000 & $0.8748^{* *}$ & $0.5133^{* *}$ & 0.1127 & 0.2236 & 0.2290 & -0.1695 \\
\hline & & G & 1.0000 & $0.9041^{* *}$ & $0.5423^{* *}$ & 0.1558 & $0.2681^{*}$ & $0.2431^{*}$ & -0.1742 \\
\hline \multirow[t]{2}{*}{2.} & \multirow[t]{2}{*}{ Days to Maturity } & $\mathrm{P}$ & & 1.0000 & $0.5564^{* *}$ & 0.1180 & 0.2096 & 0.2121 & -0.1910 \\
\hline & & $\mathrm{G}$ & & 1.0000 & $0.5892^{* *}$ & 0.1542 & $0.2721^{*}$ & 0.2275 & -0.1843 \\
\hline \multirow[t]{2}{*}{3.} & \multirow[t]{2}{*}{ Plant Height $(\mathrm{cm})$} & $\mathrm{P}$ & & & 1.0000 & 0.1882 & $0.6866^{* * *}$ & 0.0580 & $0.2627^{*}$ \\
\hline & & $\mathrm{G}$ & & & 1.0000 & 0.2176 & $0.7702^{* *}$ & $0.0748^{* *}$ & $0.2825^{*}$ \\
\hline \multirow[t]{2}{*}{4.} & \multirow{2}{*}{${ }_{1}$ Productive tillers plant ${ }^{-}$} & $\mathrm{P}$ & & & & 1.0000 & 0.0386 & 0.1655 & $0.2509^{*}$ \\
\hline & & $\mathrm{G}$ & & & & 1.0000 & -0.0235 & 0.1578 & $0.2803^{*}$ \\
\hline \multirow[t]{2}{*}{5.} & \multirow[t]{2}{*}{ Panicle Length (cm) } & $\mathrm{P}$ & & & & & 1.0000 & $0.2601^{*}$ & $0.3347^{* *}$ \\
\hline & & $\mathrm{G}$ & & & & & 1.0000 & $0.2726^{*}$ & $0.3657^{* *}$ \\
\hline \multirow[t]{2}{*}{6.} & \multirow{2}{*}{$\begin{array}{l}\text { Number of Filled grains } \\
\text { panicle }^{-1}(\mathrm{~g})\end{array}$} & $\mathrm{P}$ & & & & & & 1.0000 & 0.0413 \\
\hline & & G & & & & & & 1.0000 & $0.0412^{* *}$ \\
\hline \multirow[t]{2}{*}{7.} & Test weight (g) & $\mathrm{P}$ & & & & & & & 1.0000 \\
\hline & & G & & & & & & & 1.0000 \\
\hline \multirow[t]{2}{*}{8.} & \multirow[t]{2}{*}{ Grain yield plant $^{-1}(\mathrm{~g})$} & $\mathrm{P}$ & $0.4178^{* *}$ & $0.4604^{* *}$ & $0.4439^{* * *}$ & $0.3815^{* *}$ & 0.1379 & $0.4308^{* *}$ & 0.218 \\
\hline & & G & $0.4319^{* *}$ & $0.4830^{* *}$ & $0.4828^{* *}$ & $0.4662^{* *}$ & 0.1726 & $0.4411^{* *}$ & 0.3201 \\
\hline
\end{tabular}

G: Genotypic correlation

P: Phenotypic correlation

*Significant at $5 \%$ level, **Significant at $1 \%$ level 
Table.3 Direct and indirect effects (Phenotypic and genotypic path coefficients) of yield components on grain yield in rice (Oryza sativa L.)

\begin{tabular}{|c|c|c|c|c|c|c|c|c|c|}
\hline $\begin{array}{l}\text { S. } \\
\text { No. }\end{array}$ & Character & $\mathbf{P} / \mathbf{G}$ & $\begin{array}{c}\text { Days to } \\
50 \% \\
\text { Flowering }\end{array}$ & $\begin{array}{l}\text { Days to } \\
\text { Maturity }\end{array}$ & $\begin{array}{c}\text { Plant } \\
\text { Height } \\
\text { (cm) }\end{array}$ & $\begin{array}{c}\text { Number of } \\
\text { Productive } \\
\text { Tillers plant }^{-1}\end{array}$ & $\begin{array}{c}\text { Panicle } \\
\text { Length }(\mathrm{cm})\end{array}$ & $\begin{array}{l}\text { Number of } \\
\text { Filled grains }_{\text {panicle }^{-1}(\mathrm{~g})}\end{array}$ & $\begin{array}{c}\text { Test } \\
\text { weight } \\
\text { (g) }\end{array}$ \\
\hline \multirow[t]{2}{*}{1.} & \multirow{2}{*}{$\begin{array}{l}\text { Days to } 50 \% \\
\text { flowering }\end{array}$} & $\mathrm{P}$ & -0.0372 & -0.0325 & -0.0191 & -0.0042 & -0.0083 & -0.0085 & 0.0063 \\
\hline & & $\mathrm{G}$ & -0.1385 & -0.1252 & -0.0751 & -0.0216 & -0.0371 & -0.0337 & 0.0241 \\
\hline \multirow[t]{2}{*}{2.} & \multirow[t]{2}{*}{ Days to Maturity } & $\mathrm{P}$ & 0.0452 & 0.0517 & 0.0287 & 0.0061 & 0.0108 & 0.0110 & -0.0099 \\
\hline & & $\mathrm{G}$ & -0.0185 & -0.0205 & -0.0121 & -0.0032 & -0.0056 & -0.0047 & 0.0038 \\
\hline \multirow[t]{2}{*}{3.} & \multirow[t]{2}{*}{ Plant Height (cm) } & $\mathrm{P}$ & 0.3561 & 0.3859 & 0.6937 & 0.1306 & 0.4763 & 0.0403 & 0.1822 \\
\hline & & $\mathrm{G}$ & 0.5777 & 0.6277 & 1.0653 & 0.2318 & 0.8205 & 0.0797 & 0.3009 \\
\hline \multirow[t]{2}{*}{4.} & \multirow{2}{*}{$\begin{array}{l}\text { Number of } \\
\text { productive tillers }^{-1} \text { plant }^{-1}\end{array}$} & $\mathrm{P}$ & 0.0243 & 0.0255 & 0.0406 & 0.2159 & 0.0083 & 0.0357 & 0.0542 \\
\hline & & $\mathrm{G}$ & 0.0312 & 0.0309 & 0.0436 & 0.2002 & -0.0047 & 0.0316 & 0.0561 \\
\hline \multirow[t]{2}{*}{5.} & \multirow{2}{*}{$\begin{array}{l}\text { Panicle Length } \\
(\mathrm{cm})\end{array}$} & $\mathrm{P}$ & -0.0971 & -0.0910 & -0.2981 & -0.0167 & -0.4342 & -0.1129 & -0.1454 \\
\hline & & $\mathrm{G}$ & -0.1860 & -0.1888 & -0.5342 & 0.0163 & -0.6936 & -0.1891 & -0.2537 \\
\hline \multirow[t]{2}{*}{6.} & \multirow{2}{*}{$\begin{array}{l}\text { Number of filled } \\
\text { grains panicle }^{-1}(\mathrm{~g})\end{array}$} & $\mathrm{P}$ & 0.1076 & 0.0997 & 0.0273 & 0.0778 & 0.1222 & 0.4699 & 0.0194 \\
\hline & & $\mathrm{G}$ & 0.1371 & 0.1283 & 0.0422 & 0.0890 & 0.1538 & 0.5640 & 0.0232 \\
\hline \multirow[t]{2}{*}{7.} & \multirow{2}{*}{$\begin{array}{l}\text { Test weight } \\
(\mathrm{g})\end{array}$} & $\mathrm{P}$ & 0.0189 & 0.0213 & -0.0292 & -0.0279 & -0.0372 & -0.0046 & 0.1113 \\
\hline & & $\mathrm{G}$ & 0.0289 & 0.0305 & -0.0468 & -0.0465 & -0.0606 & -0.0068 & 0.1657 \\
\hline \multirow[t]{2}{*}{8.} & \multirow[t]{2}{*}{ Grain yield plant $^{-1}$} & $\mathrm{P}$ & $0.4178^{* *}$ & $0.4604^{* *}$ & $0.4439 * *$ & $0.3815^{* *}$ & 0.1379 & $0.4308^{* *}$ & 0.2180 \\
\hline & & $\mathrm{G}$ & $0.4319^{* *}$ & $0.4830^{* *}$ & $0.4828^{* *}$ & $0.4662^{* *}$ & 0.1726 & $0.4411^{* *}$ & 0.3201 \\
\hline
\end{tabular}

Genotypic Residual effect $=0.5754, \mathrm{P}:$ Phenotypic level

Phenotypic Residual effect $=0.6771, \mathrm{G}:$ Genotypic level

*Significant at $5 \%$ level, ${ }^{* *}$ Significant at $1 \%$ level Diagonal values indicate direct effects 
Character association studies provided information only on the inter association of yield components showed the nature and extent of their relationship with each other whereas Path coefficient analysis permits a thorough understanding of the contribution of the various characters by portioning the correlation coefficient into components of direct and indirect effects.

Path coefficient analysis was based on correlation coefficient using grain yield as the dependent factor (effect) and fix other quantitative characters as independent characters (cause). The results of the present investigation on path analysis presented in (Table 3) revealed that the direct effects of plant height, number of productive tillers per plant and number of filled grains per panicle were positive with grain yield per plant and other traits like days to $50 \%$ flowering, days to maturity and panicle length showed negative direct effect for grain yield per plant. Rajendra et al., (2015) observed positive direct effects of plant height and filled grains per panicle for grain yield per plant and Shantanu and Debojith (2015) observed negative direct effects of days to $50 \%$ flowering and panicle length for grain yield per plant.

Test weight, showed non-significant positive correlation on grain yield per plant coupled with positive direct effect. Similar results of positive direct effect of test weight on grain yield per plant was reported by Rangare et al., (2012). The high residual effect in the present study indicated that beside the characters studied, there are some other attributes for grain yield per plant. This result is in concurrence with findings reported by Selvaraj et al., (2011). Hence, considering the nature and magnitude of character association and their direct and indirect effects, it can be inferred that simultaneous improvement of grain yield per plant is possible through manifestation of plant height, number of productive tillers per plant and number of filled grains per panicle.

\section{References}

Basavaraja, T., Asif, M., Mallikarjun, S. K. and Gangaprasad, S. 2013. Correlation and path analysis of yield and yield attributes in local rice cultivars (Oryza sativa L.). Asian Journal of Biological Sciences 8: 36-38.

Borbora, T. K., Hazarika, G. N. and Medhi, A. K. 2005. Correlation and path analysis for plant and panicle characters in rice (Oryza sativa L.). Crop Research. 30 (2): 215-220.

Bornare, S. S., Mitra, S. K. and Mehta, A. K. 2014. Genetic variability correlation and path analysis of floral, yield and its component traits in CMS and restorer lines of rice (Oryza sativa L.). Bangladesh J. of Botany. 43(1): 45-52.

Dewey, D. R. and Lu, K. H. 1959. A Correlation and path coefficient analysis of components of crested wheat grass seed production. Agronomy Journal. 51(9): 515-518.

Falconer, D. S. 1964. An Introduction of Quantitative Genetics-Second edition. Oliver and Boyd, Edinburgh. 312-324.

FAO (2004) Proceeding of the FAO rice conference International Rice Commission New Steller Special Edition. 53: 17-19

Fisher, R. A. and Yates, F. 1963. Statistical Tables for Biological, Agricultural and Medical Research Oliver and Boyd. Publishing Cooperative Pvt. Ltd. London. 46-63.

Kole, P. C., Chakraborty, N. R and Bhat, J. S. 2008. Analysis of variability, correlation and path coefficient in induced mutants of aromatic nonbasmati rice. Tropical Agricultural Research and Extension. 11: 60-64. 
Ministry of Agriculture 2014-2015. Government of India.

Rajendra, K. P., Radha Krishna, K. V., Bhave, M. H. and Subba Rao, L.V. 2015. Correlation and path coefficient analysis for yield and yield component traits in boro rice (Oryza sativa L.). International J. of Tropical Agriculture 33(2): 735-740.

Rangare, N. R., Krupakar, A., Ravichandra, K., Shukla, A. K. and Mishra, A. K. 2012. Estimation of characters association and direct and indirect effects of yield contributing traits on grain yield in exotic and Indian rice (Oryza sativa L.) germplasm. International Journal of Agricultural Sciences 2(1): 54-61.

Ratna, M., Begum, S., Husna, A., Dey, S. R. and Hossain, M. S. 2015. Correlation and path coefficient analysis in basmati rice. Bangladesh Journal of Agricultural Research. 40 (1): 153-161.

Saikumar, S., Saiharini, A., Ayyappa, D., Padmavathi, G. and Shenoy, V. 2014. Heritability, correlation and path analysis among yield and yield attributing traits for drought tolerance in an interspecific cross derived from Oryza sativa $\mathrm{x} O$. glaberrima introgression line under contrasting moisture regimes. Notula Scientia Biologicae 6 (3): 338-348.

Selvaraj, I. C., Nagarajan, P., Thiyagarajan, K., Bharathi, M. and Rabindran, R. S. 2011. Genetic parameters of variability, correlation and pathcoefficient studies for grain yield and other yield Attributes among rice blast disease resistant genotypes of rice (Oryza sativa L.). African Journal of Biotechnology 10(17): 3322-3334.

Shantanu, D. and Debojit, S. 2015. Correlation and path analysis of morpho-physiological and yield traits in boro rice (Oryza sativa L.). Agricultural Science Digest. 35 (4): 256-262.

Swain, B. and Reddy, J. N. 2006. Correlation and path analysis of yield and its components in rainfed lowland rice genotypes under normal and delayed planting conditions. Oryza. 43 (1): 5861.

\section{How to cite this article:}

Sudeepthi, K., D.P.B. Jyothula, Y. Suneetha and Srinivasa Rao, V. 2017. Character Association and Path Analysis Studies for Yield and its Component Characters in Rice (Oryza sativa L.). Int.J.Curr.Microbiol.App.Sci. 6(11): 2360-2367. doi: https://doi.org/10.20546/ijcmas.2017.611.279 